\title{
The Strategy of Growth and Economic Development in Indonesia
}

\author{
Puji Iswanto \\ Department of Mechanical Engineering, Faculty of Engineering, Universitas Negeri Jakarta, Jakarta, Indonesia \\ Email address: \\ pujiiswanto10@gmail.com
}

\section{To cite this article:}

Puji Iswanto. The Strategy of Growth and Economic Development in Indonesia. International Journal of Science and Qualitative Analysis. Vol. 1, No. 2, 2015, pp. 29-32. doi: 10.11648/j.ijsqa.20150102.13

\begin{abstract}
Economic development became something expensive for countries retarded. Therefore, they must establish a strategy to overcome barriers that exist in the country. The purpose of this article is to give an overview of the theories and strategies in economic development so that it can be understood by the reader. Strategies to overcome obstacles and build a country's economy, among others, is the theory of low-level equilibrium trap, cumulative causation theory, the cycle of poverty, the strategy of critical minimum effort, and balanced development strategy. These strategies can actually be implemented. However, not all countries can do so because of various obstacles. It requires a long time and substantial capital expensive even for underdeveloped countries.
\end{abstract}

Keywords: Development Economic, Growth Economic, Economic Strategy

\section{Introduction}

Economic countries in the world have different levels. In this case there is a classification in which there is the socalled developed countries, countries developing and poor countries. Developed countries to master the various productive sectors which encourages economic growth of the country. Availability of experts and adequate technological support of developed countries to grow toward the more advanced. Meanwhile, developing countries have weaknesses which causes them difficulty to build its economy. Lack of experts led to natural resources can not be empowered maximally. Therefore, the underdeveloped countries to allow developed countries to manage their natural resources in a cooperative relationship. However, turns the developed countries take advantage of these conditions to obtain profit profuse. Deteriorating environmental conditions cause various disaster in underdeveloped countries. It is a challenge and obstacles faced by underdeveloped countries.

This world is populated by a handful of rich countries. They exploit natural resources of underdeveloped countries to be empowered. Furthermore, raw material obtained from underdeveloped countries is processed into finished products then resold.

Economic development became something expensive for countries retarded. Therefore, they must establish a strategy to overcome barriers that exist in the country.
Purpose of Article

Provide an overview of the theories and strategies in economic development so that it can be understood by the reader.

\section{Discussion}

\subsection{The Theory of Low-level Equilibrium Trap}

This theory is the brainchild of R. Nelson. This theory is also based Malthus hypothesized that the population of a country will tend to increase when per capita income rises above the level of the minimum subsistence costs. On Initially, the population is growing rapidly along with the increase in income per capita. However, population growth rate will start to decline if it has reached the physical limits above as further increases in per capita income. This theory is similar to the strategy Leibenstein thesis minimum effort critical. According to Nelson, the disease can be diagnosed as retarded the country's economy as stable equilibrium level of income per capita at or close to the needs cost of living.

Nelson In theory, there are four conditions that bring technological and social low-level equilibrium trap, namely:

1. The high correlation between the level of per capita income and growth rate population

2. A low tendency to use per capita income in addition to increased investment per capita

3. Lack of arable land 
4. The production method is not efficient

Moreover, inaction cultural and economic slowdown is also a factor which became the trap. Nelson uses three types of relationship to describe the economic trap at low income levels, namely:

1. Revenue is a function of capital stock, the level of technology, and the size of the population

2. Investments net consists of capital that is created from savings in the form of additional material on the new land area of land that is being processed

3. With low per capita income, short-term changes in the rate population growth is a result of changes in mortality, and changes in the death rate was a result of changes the level of per capita income. However, while revenue per capita reached a level far above the necessities of life. The next increment on a per capita income less effect on mortality

In theory, Nelson stressed a number of factors needed to escape from the trap of low-level equilibrium, namely:

1. The social and political environment that is favorable in country concerned

2. The social structure must be changed to provide greater pressure on saving and entrepreneurship. Greater incentive to be given to produce more and to limit the amount of family.

3. Steps should be taken to change the distribution of income, on the same time allows the accumulation of wealth by the investor.

4. The government's overall investment program.

5. Income and capital shall be increased by funds from outside country.

6. The production technology is more adequate.

\subsection{Cumulative Causation Theory}

In 1955, Professor Gunnar Myrdal promoted that regions advanced experience accumulated a competitive advantage over those areas develops. If an area experiencing growth, the development of will give effect to other areas. Professor Myrdal states that spread impact in underdeveloped countries ruled by turning effect. Ironically, market forces and free trade tends to hamper export potential underdeveloped countries because their products are removed by the product states forward.

Relationships cooperation between developed countries with state it led to growing inequality in terms of economic development. Developed countries obtain dispersive effects that push the pace of development the country's economy. Instead, developing countries acquire reverse impact of these cooperative relationships that hamper their economic development. Developed countries have to strangle the economy of developing countries. They sell their products to developing countries at a price which much cheaper so that national and regional products be eliminated. There is no denying, developed countries are mastering technology has become vicious poverty for underdeveloped countries. It can be said developed countries have haunt underdeveloped countries. Regional inequality has a close relationship with profit-motivated capitalist system. Regional imbalances are becoming increasingly severe if a region is growing at the expense of other areas experiencing stagnation. In essence, the economic development becomes a thing ekspensif and very long for the underdeveloped countries. This opinion is reinforced by evidence pointing apparent that Professor Myrdal's thesis proved to be true.

Professor Myrdal promoted three important conclusions are:

1. The world is populated by a handful of countries that are very rich and number large state-regara very poor

2. Rich countries implementing economic development pattern continues constantly while poor countries progressing very slow and there is even stagnate

3. Economic inequality gap between rich countries and countries poor more and more increase great

\subsection{The Cycle of Poverty}

The cycle of poverty or the poverty trap that theory circle a set of forces that affect each particular cause a country becomes poor and very slow to develop. this matter be the background to the strategy of balanced development in the countries develops.

According Nurkse, a country is poor because it is a poor country. There are two types of poverty trap a barrier for developing countries, which offers capital and demand for capital. In the event that the capital offers, low income levels caused by low productivity resulting capability people to save too low. This led to the formation of capital in a country becomes low. Thus, the level of productivity of a country will remain low. In terms of demand for capital, limited market area stimulants cause low capital investment. Low stimulants this capital investment is also influenced by the low income communities due to the low productivity of the public. Limited formation past capital is a form of low productivity due lack of stimulation of investment. Meier and Baldwin added, in addition to the poverty trap above, the poverty trap also arise due to underdevelopment of society still traditional with natural wealth is still not empowered.

Thus, it can be concluded that the poverty trap influenced by the following factors:

1. People are not able to manage the savings properly

2. Lack of stimulants in terms of capital investment

3. Lack of education and knowledge society

4. The lack of experts and low skill levels of society.

\subsection{Strategy of Critical Minimum Effort}

Professor Harvey Leibenstein found backward country gripped the vicious cycle of poverty that causes them to stick around equilibrium level of income per capita is low. Therefore, the strategy critical minimum effort became a way out of this impasse. By raising income per capita at the level of sustainable development, then the rate of population growth occurs. However, the increase in per capita income beyond a certain point would lower fertility rates. When construction reached the advanced stage, the population 
growth rate will drop. Population growth is a function of income per capita. According to thesis Dumont, rising per capita income will reduce the desire for obtain offspring. In addition, increased specialization and mobility economic and social. Thus, the rate of population growth becomes constant and decline. As for the factors that affect the growth of revenue per capita of implementation efforts is a critical minimum internal diseconomies of scale and external diseconomies of scale. Internal diseconomies of scale as a result of factors production which can not be divided. Meanwhile, the external diseconomies of scale as a result of external dependence, cultural and institutional barriers in country develops. The entrepreneurs, investors, savers, and innovators an agent population growth. With the presence of such agents, it would appear entrepreneurship, increase sources of knowledge, skills development society, increase the rate of savings and investment.

Stimulation of the growth is divided into two, namely:

1. Stimulation Zero-Sum

This stimulation does not increase the national income but are distributive efforts, namely through:

a. Non-commercial activities with a monopolistic position, political forces and social prestige

b. Commercial activity with aggregate source adds

c. Speculative activity by wasting resources entrepreneurship rare

d. The net savings activities with social value lower than corresponding private

2. Stimulation Positive-Sum

This stimulation leads to the development of national income

From both stimuli mentioned above, the positive-sum activities that generating economic development. However, conditions in underdeveloped countries no thus enabling entrepreneurs tend to implement a zero-sum activity. In the underdeveloped countries, there is some influence of anti change so that pressing per capita income, namely:

1. The operations of zero-sum intended to defend the rights of economic special restrictions exist through economic opportunities which has the potential to develop

2. Conservative measures the workers who organized or unorganized which aims to oppose the change

3. Resistance to new ideas and knowledge as well as appeal classical knowledge and old ideas

4. The increase in luxury consumption expenditures are essentially private or public unproductive by using resources that could used for capital accumulation

5. The growth of the population and labor force growth caused by other things remain the same has the effect that diluting capital available per worker

6. The capital output ratio is high

With the critical minimum effort, the per capita income will rise and tend to raise savings and investment resulting in:

1. Expansion of growth agents

2. The Community contribution per unit of capital to increase as the ratio of capital output fell
3. Reduced the effectiveness of the factors that inhibit growth

4. Creation of environmental and social conditions so that economic mobility and social rise

5. Increased specialization and the development of secondary and tertiary sectors

6. The creation of a suitable climate for change is to bring economic and social change, especially in the environment so that declining fertility and population growth rate

\subsection{Balanced Development Strategy}

The term balanced development was first raised by Professor Paul N. Rosenstein-Rodan in 1953 who later introduced by Nurkse on the same year. Theory initiated a massive boost to create development in Eastern Europe and Southeast with large scale industrialization. Balanced development strategy also called the theory of a massive boost by building a variety of inter-related industries massive at the same time. This strategy covers a variety of sectors complementarity, where construction is done simultaneously and harmoniously. This strategy is intended that the development process is not difficult to obtain raw materials, expertise, energy resources and markets.

According to this theory, in a major development program is needed thorough in the form of a minimum amount of investment. How it works slowly little will not push the economy to the level of development. In this case, Rosenstein-Rodan distinguish between three kinds of requirement to an absolute minimum and external economies, namely:

1. Absolute Minimum Requirements in the Production Function

These include a minimum investment requirement of input, output or process. Initial capital in this function, among others, energy, transport, and communications.

2. Absolute Minimum Requirements on Demand

In order not to risk his shortage of market or markets, it takes a stance. Companies that are interrelated. For example, companies in the industrial sector and agriculture, foreign and domestic, productive sector and infrastructure.

3. Absolute Minimum Requirements on Stocks Savings

Saving is the minimum requirement in the investment. When revenue increases, the marginal savings rate should be higher than the average rate savings.

With an absolute minimum of three requirements above and the presence of external economies can be developed, then the minimum amount of investment is the only way to overcome obstacles to development in underdeveloped countries.

\section{Conclusion}

Each country can not be separated from economic development. In improving the country's economy, it is necessary strategies steadily. Besides that, capital or investment is a major requirement that must be owned by a 
country.

Low-level equilibrium trap theory says the same thing with strategies critical minimum effort according Malthus hypothesized that the population of a country will increase if the income per capita increases. Nelson In theory, there are four technological and social conditions that bring trap equilibrium level low. Nelson also uses three types of relationships to describe the trap economy on a low income. In addition, Nelson stressed a number of factors needed to escape from the low-level equilibrium trap.

Cumulative causation theory proposed by Professor Myrdal stated that cooperative relationship between the developed and developing countries had caused inequality. Developed countries benefit most from such cooperation. Meanwhile, developing countries receive the impact behind it.

In theory circle of the poverty trap, it turns out the construction in a country is determined by the condition of the country itself. Backward state of society and still traditional and natural resources that are less empowered cause low productivity. Low productivity become obstacles to the community acquire real incomes so that their savings be low. Furthermore, low savings lead to low capital formation resulting capital formation of a country becomes low.

Strategy of critical minimum effort put forward by Professor Leibenstein. According to him, per capita income is the foundation of economic development. With raising the per capita income at the level of sustainable development, then there is the rate of population growth. Meanwhile, population growth is a function of income per capita. With rising per capita income, people's desire to obtain offspring will decline. Diseconomies of scale internal and external are the two factors that affect the per capita income.

Balanced development strategy aims to promote development economy by establishing industries in various sectors are interrelated at the same time. With the presence of these industries will create a condition that is mutually beneficial for every company need each other. In addition, it takes an absolute minimum requirements so that these strategies can be fulfilled.

These strategies can actually be implemented. However, not all countries can do so because of various obstacles. It requires a long time and substantial capital expensive even for underdeveloped countries.

\section{References}

[1] Indriantoro, Nur. 1999. Metodologi Penelitian Bisnis untuk Akuntansi \& Manajemen. Yogyakarta: Penerbit BPFE.

[2] Jhingan, M.L. 1990. Ekonomi Pembangunan dan Perencanaan. Jakarta: CV Rajawali.

[3] Philip Kotler, et al. 2000. Manajemen Pemasaran Perspektif Asia. Yogyakarta: ANDI \& Pearson Education AsiaPte. Ltd.

[4] Sukirno, Sadono. 1985. Ekonomi Pembangunan. Jakarta: Lembaga Fakultas Ekonomi UI dengan Bima Grafika.

[5] Tjiptono, Fandy \& Anastasia Diana. 2003. Total Quality Management (TQM). Yogyakarta: Penerbit Andi.

[6] Wahyu, Y. Istiyono \& Ostaria Silaban. 2006. Kamus Pintar Bahasa Indonesia. Batam: Karisma Publishing Group.

[7] http://www.smecda.com/Buku Sorotan/1KELEMBAGAAN/2-PEMERINGKATAN/8 Pemeringkatan-executive.pdf

BAB $\% 202-$

[8] http://sudjilah.lecture.ub.ac.id/2010/05/ekonomipembangunan-2/

[9] http://sucisetiyaningsih.blogspot.com/2009/08/strategipertumbuhan-dan-pembangunan.html

[10] http://www.wikipedia.com/ 